\title{
Who Decides? Representation and Decision- making at the International Labour Organization
}

\author{
Marieke Louis
}

\begin{abstract}
The study of international organisations most often consists of an analysis of the implementation and effectiveness of their policies. This chapter takes a different approach, and discusses the processes that prevail within the International Labour Organization (ILO), upstream of the programmes it implements; it focuses on the participants who decide what the ILo does, what it cannot do and how its mandate is fulfilled. Building on the work of Robert Cox and Harold Jacobson (The Anatomy of Influence: Decision Making in International Organizations, 1973), the author will attempt to understand how this institution has developed its process of representation and decision-making since its creation. While the tripartite dynamics of the ILO and the unique role of the trade unions and employers active within it are often underlined, it will be seen that its decision-making process also responds to other logics underpinned by the political and economic balance of power (East/West, North/South, industrialised countries/developing countries), by organisational dynamics (the relative autonomy and expertise of its secretariat and director general) and by external pressures (non-governmental organisations). Based on an analysis of representation in the ILO, this chapter reveals the complexity of its decision-making process. It shows that this institution does not fundamentally upset the traditional balance of power between states, but that its influence also arises from certain structural arrangements and ways of making representation work.
\end{abstract}

\section{Introduction}

The International Labour Organization (ILO) is first and foremost known for the missions entrusted to it: the improvement of working conditions, the achievement of social justice and the creation of decent jobs. This mandate is set forth in the founding texts of the Organization: Part XIII of the 1919 Treaty

(C) MARIEKE LOUIS, 2019 | DOI:10.1163/9789004399013_004

This is an open access chapter distributed under the terms of the prevailing CC-BY-NC license at the time of publication. 
of Versailles which became the ILO Constitution, ${ }^{1}$ the 1944 Declaration of Philadelphia, ${ }^{2}$ the 1998 Declaration on Fundamental Principles and Rights at Work, ${ }^{3}$ the 2008 Declaration on Social Justice for a Fair Globalization ${ }^{4}$ and the 2009 Global Jobs Pact. ${ }^{5}$ Much academic work has studied the ILO by focusing on its mandate and the tools and resources it uses to implement it (Alcock, 1971; Bonvin, 1998; Cayet, 2010; Ghebali, 1989; Haas, 1964; Hughes and Haworth, 2011; Kott and Droux, 2013; Lespinet-Moret and Viet, 2011; Louis, 2011; Maupain, 2013; Van Daele et al., 2010). It has at its disposal normative instruments of a more or less binding nature: international labour conventions, recommendations, resolutions and declarations. It also deploys practical tools-often grouped under the category of 'technical cooperation'-which consist in the provision of funds and the dispatch of ILO experts to the various member countries. Among these instruments, which aim to ensure the local application of international standards and the dissemination of good practices (Klein et al., 2015), the ILO attaches particular importance to the training of members of governments, trade unions and employers' organisations on subjects within its competence; most of the time this training is provided by the Turin International Training Centre, established in 1964.

These studies tell us a great deal about what the Organization does and how it does it, but they do not necessarily answer another important question: 'Who decides what the ILo does?' To identify the participants in the decisionmaking process, it is necessary to position oneself upstream of the institution's policymaking, whether this concerns standards, cooperation or, increasingly, development with a view to achieving the goal of social justice. ${ }^{6}$ It is also necessary to take another look at two fundamental aspects of the study of international organisations from a political science perspective, asking how representation, on the one hand, and decision-making, on the other, can help us better understand power relationships, which are often absent from official organisation charts. In political science, representation, decision-making and

1 See the Constitution on the website http://www.ilo.org/dyn/normlex/en/f?p=100o:62:0::NO: 62:P62_LIST_ENTRIE_ID:2453907:NO (accessed on 19 June 2018).

2 See the Declaration on the website http://www.ilo.org/dyn/normlex/en/f?p=100o:62:0::NO: 62:P62_LIST_ENTRIE_ID:2453907:NO (accessed on 19 June 2018).

3 See the Declaration on the website http://www.ilo.org/declaration/lang--en/index.htm (accessed on 19 June 2018).

4 See the Declaration on the website http://www.ilo.org/wcmsp5/groups/public/---dgreports/--cabinet/documents/genericdocument/wcms_371208.pdf (accessed on 19 June 2018).

5 See the Pact on the website http://www.ilo.org/jobspact/about/lang--en/index.htm (accessed on 19 June 2018).

6 See also the chapters in this volume by Sandrine Kott (Chapter 2) and by Patricia Vendramin and Agnès Parent-Thirion (Chapter 13). 
power are distinct but often interlinked concepts and processes. In its Weberian sense, power can be defined as the opportunity for a certain person to impose his or her will in a social relationship characterised in particular by coercion and domination. We will not tackle the question of power in its entirety here, but we will examine one aspect of it: the link between representation and decision-making, in the sense that the chances of a person imposing his or her will are greater if that person is in a position to make decisions. But the ability of a person to influence decisions does not necessarily determine his or her ability to enforce them in the field.

In this chapter, we will focus on the evolution of the representation of the tripartite members of the ILO (states, trade unions and employers' organisations), officials of the Organization, and also participants who are a priori more external to the ILO - that is to say, non-governmental organisations. We argue that being represented in the Organization is a necessary but not a sufficient condition to influence the decisions made and the policies implemented. Influential participants have a number of attributes, including financial and personal investment, longevity, and adherence to the Organization's tripartism and values. We will set out this argument in a first section devoted to the study of the representation of ILO members on the Governing Body-the ILO's restricted executive body, which meets three times a year in Geneva. The Governing Body is not the only place of power within the ILO since norms are adopted by the International Labour Conference (the annual general assembly of ILO members) and since some of its commissions-the Conference Committee on the Application of Standards for example-play a key role in normative policies. But it remains the space of representation that is most valued and most coveted by Organization members. In the second part, we will show that some participants (state and non-state) have had great difficulty in making their voices heard, but that they have succeeded, through contestation, in reforming the process of representation while remaining on the sidelines.

\section{$2 \quad$ Who Decides in International Organisations?}

\subsection{States are Central but Not Exclusive Participants in the Process}

The most intuitive answer to the question posed in this section is obviously the state; states - the creators of these organisations - therefore play a part in decisions that depend on their relative power, evaluated according to various criteria (military, economic, cultural, social, etc.). Within the ILO, at least two bodies must be distinguished: on the one hand, the International Labour Conference (ILC), which negotiates and adopts (through substantive work in 
committees) international labour standards, and on the other hand, the Governing Body, the restricted executive body of the Organization. It had 24 members in 1919 and since 1995 it has had 122 members ( 56 full members and 66 deputy members). Among the members of the Governing Body, ten (initially eight) are not elected but represented de jure because of their industrial power (Louis, 2016a): Brazil, China, France, Germany, India, Italy, Japan, Russia, the United Kingdom and the United States. These states are not permanent members in the strict sense of the term, since the classification of states according to their industrial power may vary. Nevertheless, this list has only rarely changed in the history of the Organization: the last modification dates back to 1983. Although the majority of the members of the Governing Body are elected every three years by the ILC, this election is most often a mere formality. New entrants are co-opted upstream by the International Trade Union Confederation (ITUC) as regards workers, the International Organization of Employers (IOE) as regards employers, and finally by the regional groups as regards governments.

The role of the Governing Body has been considerably strengthened since 1919. Although the founding fathers of the ILO had initially assigned to it solely the task of drawing up the agenda and the direction of the ILO, its powers in fact went far beyond. Over time, the Governing Body has become one of the most important, if not the most important, bodies of the ILO. It elects and appoints its Director General without any formal need for the agreement of the ILC. It also has the power to create commissions of inquiry. In addition, whereas the adoption of the budget is, in principle, the responsibility of the ILO, the Governing Body prepares it on the basis of the proposals of the Director General. After the Second World War, the Governing Body was even given the ability to influence its own composition: it has since then had the task of determining, in the last resort, the classification of states according to their industrial power. In the members' eyes, the Governing Body is thus the place where 'everything is at stake'.

As mentioned earlier, the list of the most industrialised states occupying a de facto permanent seat has remained quite unchanged, despite significant developments in recent years with regard to the regular budget of the Organization, which is subject to a fixed scale, unlike the voluntary contributions of members (ILO, 2011, Table 5; ILO, 2017, 65-69). The United States remains the largest contributor, with 22 per cent of the regular budget; Japan represents only 9.684 per cent (compared with 16.631 per cent in 2010); Germany 6.392 per cent (compared with 8.581 per cent in 2010); the United Kingdom 4.465 per cent (compared with 6.645 per cent in 2010); and France 4.861 per cent (compared with 6.304 per cent). Italy's contribution has also fallen slightly 
(from 5.081 per cent to $3.75^{\circ}$ per cent). On the other hand, China has seen the amount of its contributions increase considerably, from 2.668 per cent in 2010 to 7.924 per cent in the last budget plan, as have Brazil (from 1.201 per cent in 2010 to 3.825 per cent) and Russia (from 1.201 per cent to 3.089 per cent). Only India remains below the 1 per cent threshold. Thus, the largest industrial powers are not necessarily the largest contributors, and vice versa; Canada, Mexico and Spain have long made higher contributions than Brazil, Russia or India (Louis, 2016b, 388). The so-called ordinary ILo budget is financed by the fixed contributions of the states (also known as mandatory or statutory contributions) according to a scale common to the agencies of the United Nations (UN) system. The amount of these contributions is therefore not specific to the ILO and does not necessarily reflect a particular commitment of members to the Organization-since it is largely proportional to their gross domestic product. But these amounts represent only a part of the ILO's total resources. To have a comprehensive view of each state's contribution and voluntary commitment, voluntary and extra-budgetary contributions as well as the Organization's Regular Budget Supplementary Account (RBSA) should be taken into account. For the 2018-19 period, these two budgets are estimated at USD $45^{\circ}$ and USD 36.4 million, respectively, compared with USD 625.9 million $^{7}$ for the regular budget (ILO, 2017). Under these two types of voluntary contributions, the United States, the European Union, Australia, Norway and the Netherlands top the list of the thirty largest contributors for the period 2012-15; Brazil and Russia rank respectively no higher than $17^{\text {th }}$ and 23 rd, while China and India are not even included in the rankings. ${ }^{8}$

These indicators make it possible to draw up an initial inventory of the material investment of states within the ILO, but they are insufficient to account for the capacity of the former to influence the decisions taken by the Organization as a whole.

Other participants influence the decisions taken, in general, by international organisations. In the case of the ILO, these participants are evident precisely because of the Organization's tripartite composition. This involves the representation of trade unions and employers' organisations (in particular

7 It should be noted that, since 1991, the Director General has also been authorised to receive, on behalf of the Organization, donations from public and private organisations (including workers' and employers' organisations).

8 Multi-bilateral Development Partner and EC Ranking Total Extra-budgetary Development Cooperation (ХвтC) and RBSA Contributions (2012-15) can be viewed on the website http:// www.ilo.org/wcmsp5/groups/public/---dgreports/---exrel/documents/genericdocument/ wcms_206667.pdf (accessed on 12 February 2018). 
those affiliated to the ITUC and the IOE), which are placed on an almost equal footing with states in all the bodies of the ILO, and in particular in the Governing Body. While tripartism is specific to the ILO in the world of international organisations, other institutions involve non-state participants in their decision-making - for example, the International Organization for Standardization (Louis and Ruwet, 2017), and at the national level, joint bodies such as economic and social councils.

Tripartite participants are recognised as constituent members of the ILO and the only ones officially empowered to make decisions. Only they have the right to vote, even though a large number of decisions are taken by consensus. But other participants can play, in a more informal way, a decisive and even decision-making role.

In observing the functioning of international organisations, it is easy to highlight the key role of the secretariat (officials and the like, directors general and secretaries general). During the interviews conducted as part of this research, delegates often referred to the ILO's more 'quadripartite' than tripartite character, with the International Labour Office being designated as the fourth key player in the institution. The extensive theoretical literature on the 'principal-agent' relationship (Bauer, 2007; Reinalda and Verbeek, 1998) has highlighted the relative independence of the secretariat (the 'agent', or the one who executes an order) from the states (the 'principal', or the one who gives the order) in various organisations. The secretariat can influence the development and implementation of policies and guide negotiations in their preparatory phases. It is recognised by other organisations as the legitimate representative of the Organization and benefits from its permanent character (Barnett and Finnemore, 2004; Strange, 1998). The workings of the ILO confirm the conclusions of its work, since the leading role of the International Labour Office, headed by the Director General of the Organization, is well established. For example, between 1919 and 1932, Albert Thomas, then Director of the ILO, played a notorious role in empowering the Secretariat in relation to states, but also in relation to the League of Nations. More recently, other directors have distinguished themselves by their influence, including Juan Somavía and his iconic use of the 'creative leadership' highlighted by Ernst Haas (Haas, 1964; Louis, 2011). Juan Somavía, who was the first Director General from a southern country (Chile), led the International Labour Office from 1998 to 2012 and, in 1999, launched the Decent Work Agenda. This set of reforms was intended to mark the repositioning of the ILO on the international scene, to be the standard bearer of the strategy developed by the Organization to renew itself and gain recognition from the outside world after the end of the Cold War (Louis, 2011; Louis and Maertens, 2014). 
2.2

The Anatomy of Influence

In 1973, Robert W. Cox and Harold K. Jacobson edited and published The Anatomy of Influence: Decision Making in International Organizations, a landmark in the analysis of decision-making in political science and, more specifically, in the study of international organisations. Robert W. Cox's chapter on the ILO bears an evocative title: 'A limited monarchy'. The author describes the Organization as a political system 'in which influence is structured around one central figure - the executive head - who though he plays a leading role, does so subject to very real constraints' (Cox, 1973, 102). He dwells at length on the transformations that the Organization has experienced since the $1960 \mathrm{~s}$ and extends the analyses published by Harold Jacobson in the 1950s and 196os on the place of the Union of Soviet Socialist Republics (USSR) within the ILO by studying in particular the under-representation of developing countries and the Soviet Union. Jacobson had already stated: 'In formal terms alone, membership does not always carry with it full representation in all organs. And political influence is rarely directly proportionate to numerical strength' (Jacobson, 1960, 406).

After decolonisation, the number of ILO member states increased considerably, without however leading to a substantial change in the composition of the Governing Body and, consequently, decision-making power in the ILO. Thus, when the USSR rejoined the ILO in 1954, every effort was made to ensure that no Soviet employers' or workers' representative was elected to the Governing Body and to limit the influence of communist countries in commissions. Surprising as it may seem to the unfamiliar observer of the ILO, the USSRand Russia after the collapse of the Eastern Bloc - has never been able to exert an influence comparable to that of other permanent members of the ILO, including in non-governmental groups. A similar observation can be made with regard to China. While these two countries were permanently represented on the Governing Body as major industrial powers, it was not until the end of the 1990 s that a Russian employers' representative (with the status of deputy member) was elected and not until the turn of the new millennium that China had a workers' representative and an employers' representative (again, these were deputy members sitting in the Governing Body). The last elections to the Governing Body — for the period 2017-20-confirmed how controlled this openness of non-governmental groups actually was: on the employers' side, the Chinese and Russian representatives remained deputy members; on the workers' side, the Chinese representative was given the status of titular member, but the Russian representative remained a deputy member. Unlike regular members (also called titular members), deputy members do not have the right to vote. While most decisions are taken by consensus, voting is still practised, especially 
for important political decisions such as the election of the Director General. Although these two states are among the most powerful in the world and are permanent members of the Security Council of the United Nations, their representation on the ILO Governing Body remains carefully monitored so as to prevent the Organization from deviating from its original mandate. From a Coxian perspective, the ILO thus seems to function as a Western monarchy of industrialised countries (or more precisely as an oligarchy, insofar as decisions are taken by several participants).

Cox's perspective corroborates the above analyses by noting that the decisions taken in the ILO depend to a large extent on International Labour Office officials, whose recruitment is closely monitored by the states: '[...] the constituents keep a close eye upon the composition of the staff particularly at the upper levels' (1973, 108).

\subsection{The Long-term Nature of Individual Representation}

Why pay so much attention to the composition of the ILO Governing Body? States, like workers and employers, undeniably wish to be elected to it because of the importance of its prerogatives, but above all they want to anchor their representation in the long term, and thus be regularly re-elected. This permanence or quasi-permanence of representation constitutes the main guarantee of influence within the Organization. The Governing Body is in principle renewed every three years, but in fact the elected members retain their seats for at least two terms, or many more. States, like employers and workers, have every interest in ensuring their long-term representation-in the name of the principles of continuity and efficiency of action that justified the creation of seats reserved for the largest industrial powers. In addition to being able to participate in the decision-making process (not just voting, as discussed above), delegates are able to consolidate their influence by accumulating knowledge about the Organization and its history, procedures, routines, reports and expertise. Over time, they can build relationships with civil servants-who have truly permanent appointments - and thus gain better access to information and an opportunity to distinguish themselves from the more novice members in the negotiations of normative instruments within the ILC. At conferences, new delegates usually rely on more experienced members - that is to say, usually Governing Body members who spend several weeks a year in Geneva. As a result, some delegates have, as it were, become the 'living memory' of the institution; their experience is considered to be unique, if not irreplaceable, and this argues in favour of their retention or re-election in the case of non-permanent members. On this point, our study corroborates Robert Cox's analysis of the influence of individuals and personalities on the functioning of the institution. 
As regards both large and small states, Cox evokes this organisational elite in these terms: 'a network of personalities who together play the roles of brokers and controllers. What is important is the continuity and confidence of their mutual relationships' (Cox, 1973, 127). In addition, it would be appropriate to include in this category the politicians and other persons who do not belong to the ILO but have a good relationship with its Director General - a practice that once again highlights the importance of the latter's role.

Under the rationale of continuity, the struggle for representation to be guaranteed is particularly intense within the group of workers and the group of employers. The members of these groups exercise their responsibilities for particularly long periods: the majority of delegates remain members of the Governing Body for two terms, but some retain their positions for ten, twenty or even thirty years - the record being held by the Mexican Sanchez Madariaga (1905-99) of the Mexican Confederation of Workers, who served from 1954 to 1999. Among the delegates, the most influential are the chairpersons and group secretaries, who have special links with the ITUC, the IOE, but also with the Bureau for Workers' Activities (ACTRAV) and the Bureau for Employers' Activities (ACT EMP), the two International Labour Office services in charge of relations with workers' and employers' organisations. In fact, some particularly loyal former delegates pursue their careers in one of these services as international civil servants.

Here again, tripartism can 'counter' the classic, realistic reading of power relations based on military or economic power. It can happen that nationals of middle powers, even of small states, exert a considerable influence within their group. For example, Roy Trotman from Barbados served as chair and spokesperson for the workers' group from 2002 to 2011; he was thus a regular member of the Governing Body during this period.

Workers' representatives often present Roy Trotman as a model of success, as a man who has established himself through his personal qualities, skills and charisma. He came from an insular microstate and did not represent any of the world's leading trade union organisations. He and his predecessor, M.T. Walcott, were the sole representatives from Barbados on the Governing Body since its accession in 1967. As chairman of the workers' group (2002-11) Roy Trotman thus escaped the basic trends that shape the nature of representation on the Governing Body, but only in part, because of his activities in the International Confederation of Free Trade Unions (ICFTU) (he was the first black president of the organisation), and later the ITUC, and to his being appointed by the latter.

On the government side, turnover is more substantial for states and individuals alike. Many delegates believe that this relative instability is one of the 
reasons for the lesser influence of the government group in negotiations in addition to the regional fragmentation (Louis, 2016b).

\section{Representation without Influence? The Margins of the ILO}

\subsection{State Margins: Non-European Countries, Developing Countries and Southern Countries}

Since the creation of the ILO in 1919, a number of members have protested against what they consider to be a monopolisation of power by some states, particularly the victorious powers of the First World War (though from the outset, the ILO gave Germany a prominent place that it had never found in the League of Nations). These protests, notably from Brazil, Canada, India, and South Africa, ${ }^{9}$ focused on the composition of the Governing Body. Its limited character and the fact that no representative from a 'non-European' (or 'extra-European') state-according to the terminology of the time- -was appointed were seen as evidence of an initial marginalisation of certain members of the Organization. As a consequence, the ILO amended its Constitution in 1922 so that a minimum number of seats would be granted to non-European countries. ${ }^{10}$

This brief historical review highlights an important element: ILO members view their representation as a prerequisite for their involvement in the decision-making process, and their demands in this area are consubstantial with the Organization. No one wants to be left out. Many members feel that the Governing Body is not representative of the ILC and that the system of reserved seats for the major industrial powers is both undemocratic and counterproductive-since the other members think that the norms adopted only take into account European issues.

These demands, first expressed by non-European countries, have continued throughout the twentieth century and up until today. However, they have not always been expressed by the same participants, nor in quite the same terms, although we can detect elements of regularity. During the interwar period, the protesters spoke of the marginalisation of non-European countries. During the Cold War, they spoke more about the recently decolonised countries and, above all, the Eastern Bloc countries, allies of the USSR. Western

9 We cite only the most recurrent protesters. Many countries have occasionally issued protests about their lower level of representation.

10 This provision, which came into force in 1934, was later considered obsolete and was suppressed in 1962. 
members made concessions by agreeing to the enlargement of the Governing Body and the creation of new statutes (deputy members, substitute members and observers). But the various reform commissions that have been held since the 1960 s have never endorsed the implementation of a proportional system of election of members of the Governing Body-a system that not only the Communists but other actors such as the Christian trade union workers' organisations, a minority in the global trade union movement, have also called for (Dupuy, 1987). Developing countries, for their part, felt marginalised twice over. Relatively absent from the ILO's decision-making bodies, they also had to accept the fact that the standards and programmes adopted by the ILO sometimes seemed to them unsuited to the problems they faced. As stressed by Cox: 'Government representatives from less developed countries often took the position that ILO standards were framed in the light of conditions in advanced countries and were inappropriate to their own' $(1973,112)$.

As for the 1922 amendment, some contestations did succeed. In the late 1970s, intense negotiations on the criteria for measuring industrial power finally led to Brazil's entry into the club of the 'permanent' states represented de jure on the Governing Body (Louis, 2016a). Since India and Brazil became part of the ILo's 'organisational elite' as major industrial powers, and especially since the reform of the Governing Body adopted in 1995 (see below) developing countries can no longer be considered excluded from the Governing Body. The marginalisation of African countries, however, is still an issue. The African group is indeed one of the only ones to demand, even today, a reform of the Governing Body: they favour the abolition of the seats reserved for the major industrial powers provided for by the 1986 Amendment or the integration of African states into this restrictive club. The abolition of the 'permanent' seats is indeed one of the few components of the 1986 Amendment that has not been taken over by the 1995 reform (see below, Table 3.1).

\subsection{A New 'Monarchy'? The Case of the Industrialized Market Economy Countries (IMEC)}

Despite these changes in the structure of the Organization and in particular in the formal composition of the Governing Body, it cannot be concluded that the decision-making process is being made more balanced or even more democratic. Indeed, while the Governing Body has expanded and been rebalanced on a regional basis (Africa, America, Asia and Europe), offering the different member states the opportunity to participate more in the decision-making process, it remains highly dependent on the material logics set out at the beginning of this chapter. In addition, the 'numerical' logic (number of seats, number of votes) comes up against the fact that, within the ILO as in most international 
TABLE 3.1 Comparison of the 1986 and 1995 amendments

1986 Amendment (not in vigour) 1995 Amendment

\section{Enlargement}

112 seats (112 voting members)

- governments: 56 seats

- workers: 28 seats

- employers: 28 seats

\section{Regional distribution of seats}

Africa: 13 seats

America: 12 seats

Asia: 14 seats

Europe: 15 seats

\section{Enlargement}

122 seats ( 56 voting members)

- governments: 56 seats ( 28 per-

manent members; 28 deputy

members)

- workers: 33 seats (14 permanent

members; 19 deputy members)

- employers: 33 seats (14 permanent members; 19 deputy members)

Regional distribution of seats

Africa: 13 and a half seats ${ }^{\mathrm{a}}$

America: 12 and a half seats ${ }^{a}$

Asia: 15 seats

Europe: 15 seats

2 remaining so-called rotating seats:

the first to be alternated between Africa and America, from one mandate to the next; the second to be alternated between Asia and Europe from one mandate to the next.

a Because of a 'rotating' seat that alternates between Africa and America from one mandate to the next.

SOURCE: LOUIS (2016b).

organisations, decisions are more and more frequently taken by consensus and that the use of the vote is becoming increasingly rare - the election of the Director General is a notable exception in this regard.

Although it does not have a constitutional or regulatory existence (unlike the regional groups), the group of Industrialized Market Economy Countries (IMEC) exercises most of the decision-making power at state level in the ILO. This group of about thirty states ${ }^{11}$ was established on the basis of economic

11 In 2011, the IMEC group consisted of Australia, Austria, Belgium, Canada, Cyprus, the Czech Republic, Denmark, Estonia, Finland, France, Germany, Greece, Hungary, Iceland, Italy, Japan, Lithuania, Luxembourg, Malta, the Netherlands, New Zealand, Norway, 
rather than geographical criteria and includes the main contributors to the ILO budget. The IMEC grouping was created in 1978, during the Cold War, with the aim of strengthening the links between market-economy countries when the United States left the ILO. It is worth noting that this group, with particularly strong internal cohesion, is the only one to meet almost every day during the ILC, as has been the case since the 1980s. Many positions are taken in its name, through a rotating spokesperson who changes according to the year, the conference, and the topics on the agenda. As an example, we can mention its very regular and detailed interventions in the framework of the Committee on the Application of Standards, one of the key committees of the Conference (ILO, 2013, 11/40-11/46; ILO, 2014, 13 Part 1/56).

In addition, the IMEC's representatives interviewed for the present survey expressed a greater attachment to this informal group than to their regional group, at least when it comes to representing their interests within the ILO. For the UK government representative, the IMEC is a more important group than the Western European region or even the European Union, because of the diversity of both the topics covered and the participants it brings together ('the big players'): 'IMEC has got a much higher standing. IMEC is a bigger group, so we wouldn't generally do at all [the same] as Western Europe, it [the IMEC] has a much more important role because of its coverage, and all of the big players are in the IMEC.'12 The Japanese representative also showed a greater sense of belonging to the IMEC, but for different reasons: 'Japan feels more associated with IMEC than with Asia Pacific, with the ASPAC countries; Asia is a very broad region and there are so many differences in terms of size of the countries, size of the economies, so it's not so easy for all Asian countries to agree on a simple statement on single issues. ${ }^{\prime}$

Other delegates, such as those from Australia or New Zealand, have stressed the critical importance of the IMEC, which they describe as the place where, more than in regional meetings, key issues relating to the functioning of the ILO are discussed. 'IMEC is at the forefront of those. We see it as a very important, sort of intellectual way of generating and pushing ideas. ${ }^{14}$ For Canadian government officials, the IMEC's dominating role in decision-making,

Poland, Portugal, the Republic of Korea, Romania, Slovakia, Slovenia, Sweden, Switzerland, Turkey, the UK and the US.

12 Interview with representative from the government of the UK, 4 June 2013, Geneva, International Labour Office.

13 Interview with representative from the government of Japan, 29 October 2012, Geneva, seat of the permanent mission of Japan.

14 Interview with representative from the government of New Zealand, 5 June 2013, Geneva, Palace of Nations. 
particularly with respect to the International Labour Office, is indisputable: '[...] for Canada our priority has continued to be the IMEC group, because we'd chaired that, and it has given us quite a significant voice in the organisation [...]. I think when the IMEC has something to say, the Office pays attention. And I think the workers and the employers too. Generally speaking when the IMEC expresses its views, there is a certain amount of attention paid to that'.15

However, the IMEC remains an entity specific to the government group. In the workers' and employers' groups, respectively, there is a desire to ensure the representation of organisations from the most industrialised countries, but IMEC-type groupings have not been institutionalised, at least within the ILO.

\subsection{Non-governmental Organisations: Towards 'Tripartism +'?}

The ILO is a subject of study that makes it possible to re-examine the problem of the inclusion of non-state participants in the international scene. Its unique tripartite structure has given non-state participants the opportunity to benefit from a status almost identical to that of the state participants that are members of the Organization. But we may ask whether this new positioning has, in general, given non-governmental organisations greater influence within the ILO. The answer is no. In fact, the space of non-state representation was immediately monopolised by the major international trade union and employer confederations. As early as 1919, some organisations-such as the cooperatives - felt unjustly excluded from the tripartite system of representation and the decisions taken by the ILO on matters concerning them, and argued for the expansion of tripartism. In fact, the concept of 'tripartism +' (Fashoyin, 2005), formulated for the first time during the mandate of Juan Somavía, is only one expression of this desire to see representation extended to participants from 'civil society' (a rather vague term, to say the least) whose scope overlaps that of the ILO. Social partners (workers and employers) have generally come together to oppose this enlargement, arguing in particular that non-governmental organisations (NGOS) are not representative (Thomann, 2008; Louis, 2016b), and governments have remained divided on the subject, with some being very favourable and others completely opposed.

However, civil society organisations have never been purely and simply excluded from the ILO. From the inception of the Organization, alternatives to the status of delegate were envisaged, so as to allow for participants who did not necessarily fall into the three officially represented categories. For

15 Interview with representative from the government of Canada, 10 June 2013, Geneva, Palace of Nations. 
example, the status of technical adviser allows states, as well as trade unions and employer organisations, to include a number of people with specific expertise in their delegations. In addition, like the United Nations, the ILO after the Second World War created an observer status reserved for international non-governmental organisations. This gives NGOS an observation and consultation role and facilitates their access to ILO documentation and negotiations. Observer members are themselves divided into three sub-statuses: general, regional and roster.

The influence of NGOs on decisions taken within the ILO must be analysed without generalisation. Interviewed NGO members agree that this influence varies greatly depending on the organisations themselves, but also on the topic on the agenda and the quality of the relationships they have with members, who may — or may not—pass their demands on. It seems, for example, that NGOs had a considerable influence on the Elimination of the Worst Forms of Child Labour Convention (Convention 182$)^{16}$ and, more recently, on the Convention on Domestic Workers (Convention 189). ${ }^{17}$ In interviews, many tripartite delegates stressed the importance of NGO awareness-raising work on issues that did not necessarily fall within the priority scope of the activities of social partners (Louis, 2016b, 271-276). Moreover, in 2011-the year of the adoption of Convention 189 on domestic work-a dozen delegations (among them delegations from Belgium, Brazil and the United Kingdom) included representatives of associations (sometimes trade unions) specialising in domestic work issues. However, despite their relative goodwill towards NGOs, members occasionally called their representatives to order on issues of 'behaviour'especially when they were deemed too noisy, applauding or booing certain amendments - and strictly limited the time they could speak at the opening of the work of the Commission (Louis, 2016b, 299-300).

Since its creation, the Secretariat has endeavoured to establish links with non-governmental organisations in order to broaden the sphere of influence of the Organization. In fact, the ILO considers NGOs other than trade unions and employers' bodies as potential allies, as it can benefit from their expertise, their fact-finding activities and their ability to mobilise opinion and raise awareness among the public. But since their formal prerogatives are very limited, the influence of NGOs may be considered rather insignificant (Salah-Bey,

16 See the Convention on the website http://www.ilo.org/dyn/normlex/en/f?p=NORMLEXP UB:12100:0::NO::P1210o_ILO_CODE:C182 (accessed on 19 June 2018).

17 See the Convention on the website http://www.ilo.org/dyn/normlex/en/f?p=NORMLEXP UB:12100:0::NO::P12100_ILO_CODE:C189 (accessed on 19 June 2018). 
1963, 67). According to Georg Nolte and Sergey Lagodinsky (2004, 339), "The ILO grants NGOS passive participation rights'. These authors may not take sufficient account of the diversity of NGOs present at the ILO, but it is true that these organisations are sometimes effective lobbyists and sometimes extras, or mere spectators of decisions taken by members. As a matter of fact, NGOs did not radically change the balance of power in the process of negotiating and adopting the Convention on Domestic Workers for instance.

The resilience of the tripartite norm in the field of effective decision-making is thus a given. To reflect the attitudes of both employer and worker members, Georg Nolte and Sergey Lagodinsky $(2004,325)$ speak of a 'struggle for positions' within the ILO. But this analysis is incomplete. These members, of course, occupy an important position within the ILO that they wish to preserve. But beyond that, they fear-as do governments, to some extent — that they might destabilise the collective bargaining structure as a whole. The relationship between tripartite constituents and NGOs is a recurrent issue, as evidenced by the 2002 resolution of the ILC on tripartism and social dialogue, which aims precisely at framing relations with civil society (Baccaro and Mele, 2012). Yet the debates on the role of NGOs also highlight a more fundamental issue: the redefinition of both the scope and the purpose of social dialogue today. Trade union and employer representatives fear, in particular, that greater integration of NGOs into the ILO structure may lead to the institutionalisation of forms of work deemed prejudicial to workers (hence the challenge both they and the ILO in general face: the formalisation of the informal). For its part, the workers' group (and, to a lesser extent, the employers' group) strives to ensure that its representativity is not called into question (Louis, 2016b, 194-201).

\section{4}

\section{Conclusion}

In this chapter, we have explored, from a socio-historical perspective, the links that unite representation and decision-making power within the ILO. Building on the work of Robert Cox, we have shown the sustainable nature of the concentration of decision-making power in certain forums-notably the Governing Body-and its monopolisation by certain state and non-state participants. But we have also highlighted the ability of the tripartite logic characteristic of the ILO to disrupt the traditional balance of power mechanism.

Representation is considered by both professionals and academics to be a necessary condition for participation in the decision-making process, but it is not sufficient in itself. In particular, it is not a tool for resisting certain forms of marginalisation—including the marginalisation of developing countries—in 
spite of the significant rebalancing that has taken place since the 1980 os and 1990s. Furthermore, we have identified, without exploring them though, other ways of exercising influence within the ILO, including expertise and, more generally, knowledge. Representation, then, is not the only determinant of decision-making power. To study it, it is essential to analyse the practices of representatives, practices that sometimes differ from the formal provisions of the official texts. Thus, we have shown that representation is, within an organisation, a process in motion; it evolves with the mobilisations of the participants, whether they express themselves in an openly critical or a more cooperative way, by material contributions or, as in the case of NGOs, by their capacity to demonstrate their added value during negotiations.

\section{References}

Alcock, A. (1971) History of the International Labour Organisation (London: Palgrave Macmillan).

Baccaro, L. and V. Mele (2012) 'Pathology of path-dependency? The ILO and the challenge of new governance', Industrial and Labour Relations Review, 65(2), pp. 195-224, http://www.jstor.org/stable/24368382 (accessed on 19 June 2018).

Barnett, M. and M. Finnemore (2004) Rules for the World: International Organizations in Global Politics (Ithaca, NY: Cornell University Press).

Bauer, S. (2007) 'Bureaucratic Authority and the Implementation of International Treaties. Evidence from Two Conventions Secretariats', in J. Joachim, B. Reinalda and B. Verbeek (eds.) International Organizations and Implementation. Enforcers, Managers, Authorities? (London: Routledge), pp. 62-64.

Bonvin, J.-M. (1998) L'Organisation internationale du travail. Étude sur une agence productrice de normes (Paris: Presses Universitaires de France).

Cayet, T. (2010) Rationaliser le travail. Organiser la production. Le Bureau international du travail et la modernisation économique durant l'entre-deux-guerres (Rennes: Presses Universitaires de Rennes).

Cox, R. (1973) 'ILO: Limited Monarchy', in R. Cox and H. Jacobson (eds.), The Anatomy of Influence. Decision Making in International Organizations (New Haven, CT: Yale University Press), pp. 102-138.

Cox, R. and H. Jacobson (1973) The Anatomy of Influence. Decision Making in International Organizations (New Haven, CT: Yale University Press).

Dupuy, B. (1987) Nouvelle structure de l'Organisation internationale du travail (Paris: Economica).

Fashoyin, T. (2005) 'Tripartism and Other Participants in Social Dialogue', The International Journal of Comparative Labour Law and Industrial Relations, 21(1), pp. $37-58$. 
Ghebali, V.-Y. (1989) The International Labour Organisation. A Case Study on the Evolution of UN Specialized Agencies (Dordrecht: Martinus Nijhoff Publishers).

Haas, E. (1964) Beyond the Nation State. Functionalism and International Organization (Stanford, CA: Stanford University Press).

Hughes, S. and N. Haworth (2011) The International Labour Organization: Coming in from the Cold (London: Routledge).

ILO (International Labour Organization) (2017) Draft programme and Budget for 2018-19 and other questions, Report II presented at the 106th session of the ILC Commission on the programme, the budget and the administration, GB.329/PFA/5, 329th session, March 2017, http://www.ilo.org/wcmsp5/groups/public/---ed_norm/---relconf/ documents/meetingdocument/wcms_553198.pdf (accessed on 20 June 2018).

ILO (2014) Records of proceedings of the International Labour Conference, 103rd session, http://www.ilo.org/public/libdoc/ilo/P/og616/og616(2014-103).pdf (accessed on 20 June 2018).

ILO (2013) Records of proceedings of the International Labour Conference, 102nd session, http://www.ilo.org/public/libdoc/ilo/P/og616/og616(2013-102).pdf (accessed on 20 June 2018).

ILO (2011) Programme and budget for 2010-11, Commission on the programme, the budget and the administration, GB.310/PFA/1/1, 310th session, March 2011, http://www.ilo.org/wcmsp5/groups/public/---ed_norm/---relconf/documents/ meetingdocument/wcms_153384.pdf (accessed on 20 June 2018).

Jacobson, H. (1960) 'The USSR and ILO', International Organization, 14(3), pp. 402-428, DOI: https://doi.org/10.1017/Soo20818300009887.

Klein, A., C. Laporte and M. Saiget (eds.) (2015) Les bonnes pratiques des organisations internationales (Paris: Presses de SciencesPo).

Kott, S. and J. Droux (eds.) (2013) Globalizing Social Rights. The International Labour Organization and Beyond (London: Palgrave Macmillan).

Lespinet-Moret, I. and V. Viet (eds.) (2011) L'Organisation internationale du travail. Origine-Développement-Avenir (Rennes: Presses Universitaires de Rennes).

Louis, M. (2016a) 'Les membres permanents de l'Organisation internationale du travail. Un siècle de contestations', Revue d'histoire diplomatique, 2, pp. 128-144.

Louis, M. (2016b) Qu'est-ce qu'une bonne représentation? L'Organisation internationale du travail de 1919 à nos jours (Paris: Dalloz).

Louis, M. (2011) L'OIT et le travail décent. Un agenda social pour le multilatéralisme (Paris: L'Harmattan).

Louis, M. and L. Maertens (2014) 'Des stratégies de changement dans les organisations internationales: une analyse comparée du HCR et de l'OIT', Études internationales, 45(2), pp. 183-206, DOI: 10.7202/1026588ar.

Louis, M. and C. Ruwet (2017) 'Representativeness From Within: A Socio-Historical Account of the Concept and its Uses through the Comparison of the ILO and the ISO', Globalizations, 14(4), pp. 535-549, DOI: 10.1080/14747731.2016.1201327. 
Maupain, F. (2013) The Future of the International Labour Organization in the Global Economy (Oxford: Hart Publishing).

Nolte, G. and S. Lagodinsky (2004) 'The role of NGOs in the ILO', in E. Benvenisti and G. Nolte (eds.), The Welfare State, Globalization, and International Law (Berlin: Springer), pp. $3^{21-341 .}$

Reinalda, B. and B. Verbeek (1998) Autonomous Policy Making by International Organizations (London: Routledge).

Salah-Bey, A. (1963) L'Organisation internationale du travail et le syndicalisme mondial (1945-1960) (Paris: Librairie Médicis).

Strange, S. (1998) 'Why Do International Organizations Never Die', in B. Reinalda and B. Verbeek, Autonomous Policy Making by International Organizations (London: Routledge), pp. 213-220.

Thomann, L. (2008) 'The ILO, Tripartism, and NGOs: Do Too Many Cooks Really Spoil the Broth?', in J. Steffek, C. Kissling and P. Nanz (eds.) Civil Society Participation in European and Global Governance: A cure for the Democratic Deficit? (New York: Palgrave Macmillan), pp. 71-94.

Van Daele, J., M. Rodriguez Garcia, G. van Goethem and M. van der Linden (eds.) (2010) ILO Histories: Essays on the International Labour Organization and its Impact on the World During the Twentieth Century (Berne: Peter Lang), pp. 293-312. 